\title{
$\left.\sum 9\right]$ \\ Concept of Moral Education in the Qur'an at Integrated Islamic elementary school (SDIT) Darul Huffadz Bekasi
}

\author{
*Imron Rosadi ${ }^{1}$, Ahmad Junaedi Sitika ${ }^{2}$ \\ ${ }^{1,2}$ Universitas Singaperbangsa Karawang, Jl. HS.Ronggo Waluyo, \\ Puseurjaya, Karawang, West Java, Indonesia \\ *imronrosyadie.ir@gmail.com
}

\begin{abstract}
This study aimed to explain the concept of al-Qur'an moral education at SDIT Darul Huffadz Bekasi. The research method used by the author is a type of qualitative research through a field research approach, by collecting data or materials related to the theme of the discussion and the problem, taken from trusted sources through structured interviews as well as observation and documentation, then analyzed coherently, describing all aspects involved and contained in the verses of the Qur'an which are interpreted and describe the meaning contained in the Qur'an. To support this research, the author uses supporting sources from other literature such as books, scientific journals, and so on related to the discussion. The study results stated that SDIT Darul Huffadz Bekasi has a character-building program through Islamic Religious Education with the methods used in its implementation, namely the habit method, the exemplary method and the punishment method.
\end{abstract}

Tujuan penelitian ini adalah untuk menjelaskan konsep pendidikan akhlak al-Qur'an di SDIT Darul Huffadz Bekasi. Metode penelitian yang digunakan penulis adalah jenis penelitian kualitatif melalui pendekatan penelitian lapangan, dengan mengumpulkan data atau bahan-bahan yang berkaitan dengan tema pembahasan dan permasalahannya, diambil dari sumber terpercaya melalui wawancara terstruktur maupun observasi dan dokumentasi, kemudian dianalisis dengan runtut, mendeskripsikan semua aspek yang terkandung dalam ayat-ayat al-Qur'an yang ditafsirkan dan menggambarkan makna yang terkandung dalam al-Qur'an. Untuk mendukung penelitian ini, penulis menggunakan sumber pendukung dari literature lain seperti buku, jurnal ilmiah dan lain sebagainya yang memiliki kaitan dengan pembahasan. Hasil kajian menyebutkan bahwa SDIT Darul Huffadz Bekasi memiliki program penanaman karakter melalui Pendidikan Agama Islam dengan metode yang digunakan dalam penerapannya yaitu metode kebiasaan, metode keteladanan dan metode hukuman.

Keywords: Moral Education, Qur'an Perspective, Moral Cultivation Method.

Received: October 6, 2021; Revised: November 3, 2021; Accepted: December 26, 2021 


\section{INTRODUCTION}

Nowadays, society is increasingly being plagued by various problems, especially the moral crisis in society which is very concerning, giving rise to various new issues that arise due to this, such as a lot of slander and chaos, rampant violence, unrest is unavoidable, crime is commonplace in society. Life, so that this becomes a reality of the problems faced in society entering the era of the industrial revolution 4.0 (Nisa, 2018). This phenomenon occurs a lot because it ignores life's moral or moral aspects (Anwar, 2021a). If this is continuously allowed and no special attention is paid, it will result in injustice and ignorance inherent in every individual's desires. Al-Attas said adab is a crucial concept that is essentially the core of Islamic education. Adab is a method in its conceptual structure guiding several elements in humans, such as knowledge ('ilm), charity ('amal), teaching (ta'lim) and good parenting (tarbiyah) (AlAttas, 1996). So adab must be instilled in all humans in various circles, both those who have positions and subordinates.

In a broader sense, the fields of economy, politics, social, culture, science, technology, including in the field of education, without neglecting other aspects, actually has a chain impact on the overall order of life. This means that the weakness of humanity, especially Islam, is in the field of education. If this is allowed to continue, it will reduce the level of morals and knowledge in other aspects of life (Anwar, 2021b).

In institutional education, education is often found with a verbal system, which sometimes only dictates, asks for answers, memorizes, dictates, and others. Furthermore, the memorization mentioned above is tested through written and nonwritten tests (Mahmud, 2017). Education should be a 'transfer of value'. Sometimes it becomes a 'knowledge transfer' (Marques, La Falce, Marques, De Muylder, \& Silva, 2019).

If it is only like this, then the generation that is built only acts as a recipient of information, so it can be ascertained that it has not been tested in applying moral values that should be, because moral education is not something that must only be memorized, but more than that, it needs to be practised (Daroini, Ikhwan, \& Saputro, 2020).

This explanation of the Qur'anic verses on morality presents a small part of the many verses of the Qur'an that talk about character with a brief description from Salafus Salih. In the Qur'an, many verses instruct us to adorn ourselves with commendable morals and promise a good reward in this world and a great reward in the hereafter. Allah swt said;

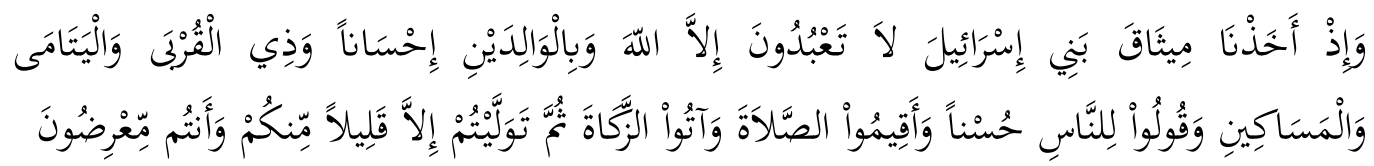

And (remember), when We took a promise from the Children of Israel (ie): Do not worship other than Allah, and do good to parents, relatives, orphans, and the poor, and say be kind to people, establish prayer and pay zakat. Then you did not fulfill that promise, except for a small part of you, and you always turned away." (QS.2:83).

Allah swt accompanies him with a call for a servant to always do good and noble behaviour to all humanity. When interpreting His words: "And speak kind words to 
people," Ali bin Abi Talib ra said, "That is against every human being." Similarly, Atha explained: "This verse commands us to treat humans well, both believers and polytheists." Allah commands His servants to be kind to everyone, be it friends or foes. In another verse, Allah swt said to Musa and Harun:

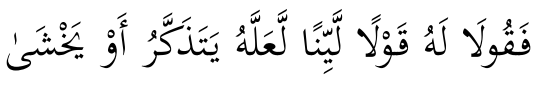

"Then speak to both of you with gentle words, hopefully he will remember or be afraid." (QS.20:44).

Among the people of the end times today, it is inevitable that they are no more noble than Musa or Harun. Besides anyone, of course, he is not worse than Pharaoh, but Allah ordered his two prophets to speak gently when talking to this ruler who claims to be God. Ibn Abbas ra even said: "If Pharaoh said to me: 'Barakallahu fik, may Allah bless you,' I would reply: 'Wa fik; And also for you." However, he died long ago." Allah swt encourages all His servants not to repay evil with the same evil because there is no equality between good and evil. Allah swt says;

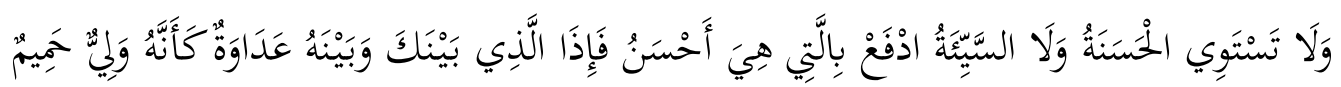

"And good and evil are not the same. Reject (the evil) in a better way, then suddenly the person between you and between him there is enmity as if he has become a very loyal friend." (QS.41:34).

At the same time, do not encourage humans to be unfair to others, so that humans on earth leave noble character. Allah swt said;

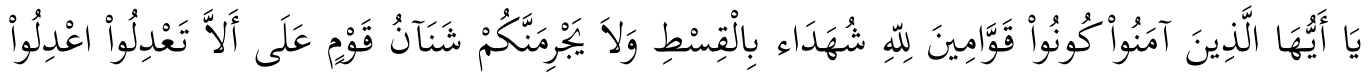

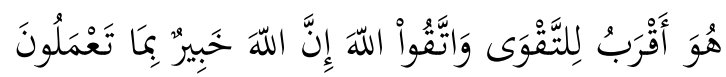

"O you who believe, be people who always uphold (the truth) for Allah, be witnesses with justice. And don't let your hatred of a people encourage you to act unjustly. Be fair, because it closer to godfearing. And fear Allah, indeed Allah is Knowing of what you do." (QS.5:8).

Ibn Taymiyya once said this verse was revealed in connection with the hatred of Muslims towards the disbelievers, and this kind of hatred in ancient times was not justified or condemned by the Shari'ah. If, in the context of syar'i hatred, it is forbidden for a person to persecute others, then what about hatred towards fellow Muslims who are (generally) born of mere interpretation and lust. Fellow Muslims certainly want to be treated well, fairly, and not persecuted. Therefore, Allah swt encourages His servants to have a forgiving nature for the injustices of others that befell them. This is summed up in his words;

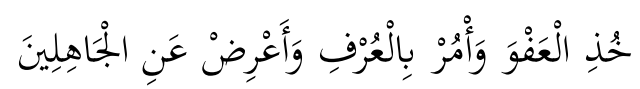

"Be forgiving and tell people to do what is right, and turn away from stupid people." (QS.7:199). 
Among the current generation or the modern generation, those who need moral strengthening start from a student's figure. According to what was obtained during his study period, there is a great responsibility in the future. Considering the level of students who are considered to be of the highest status, a student is often labelled as an agent of change because of the nation's high expectations. So that students who study at various campuses, universities, institutions, academic schools need to continue to be educated so that they continually improve their abilities, guided by moral guidance to defend themselves in the era of competition to come. Morals are an essential part of education because currently, many educational institutions make intellectual abilities the standard of success in student development and neglect the moral aspect (Althof \& Berkowitz, 2006).

Moral education is a big problem that has been a challenge for humans throughout the history of the development of civilization. The history of the nations contained in the holy books of the 'Ad, Thamud, Madyan until now held in historical manuscripts shows that a country will have a strong civilization progressing if the morals of its people are solid, but on the other hand, a nation will collapse if its morals begin to deteriorate. from the community (Maryam, Putri, \& Firmansyah, 2018).

Moral education is the education of moral wisdom, the virtue of temperament, the habits that a person has and must be used as the foundation of life since childhood. It cannot be denied that the virtue of morality and character is one of the fruits of faith in the development of true religion (Bafadhol, 2017).

Good moral education is based on a solid faith. Therefore, the cultivation of faith must use ways that touch the heart, not by coercion, because faith in the gut affects students (Sardiyanah, 2020). In this regard, the implications of the method play an important role in instilling the moral potential of students about the process of self-discovery and also in the formation of a noble soul because ethical education or moral education is the soul of Islamic education (Nabila, 2021). So it can be concluded that ethical and moral education is the spirit (soul) of Islamic education in achieving perfect morals. Therefore, the inculcation of the values of moral education to children should receive significant attention. From now on, moral development must continue to be accustomed to this, considering that the habituation of good behaviour in students must be by the pattern of development and growth (Darmadi, 2015).

Moral education in Islam recognises that there must be reasonable and evil, truth and evil, justice and injustice, and peace and war (Zulida, 2017). To deal with these contradictions, Islam has established values and principles that enable humans to live well in the world. Thus, humans can realize the goodness in this world and the hereafter and interact with others (Mardiana, Razaq, \& Umiarso, 2020).

The development of moral, educational values and habituation must start early and be planned and possible to lay the foundation and foundation of moral education in students. In addition, educators must realize that students need habituation and elaboration and exercises that are adapted to the development of their souls (Nurhartanto, 2015). Abdullah Sadjad has carried out several related studies with the title of moral education from the perspective of al-Imam Al-Ghazali (Sadjad, 2020). They are forcing and providing stimulus to foster a dynamic and creative understanding of religion, not passive. The concept of moral education must be empowered to respond to globalization. Another study was also conducted by Ibrahim Bafadhol, Moral Education in Islam (Bafadhol, 2017). One of the things emphasized 
in Islam is that moral education must start from an early age because childhood is the most conducive period for instilling good habits.

What is emphasized in Islam is that moral education must start from an early age because childhood is the most conducive period for instilling good habits. In Islamic education, Muhammad Athiyah Al-Abrasyi emphasized that moral educators are the spirit of Islamic education. Islamic education is education with ethics and morals that aims to achieve moral perfection (Ikhwan, 2019).

In his book, Al-Ghazali, quoted by Syamsu Yusuf, does not recommend using only one method to deal with children's problems and implement children's moral education. The teacher must choose an educational plan according to his age, catch and place according to his personality (Syamsu, 2015). Therefore, efforts to educate and guide their potential as optimally as possible so that educators in the field of moral education, students need and are encouraged to understand children's development.

\section{Moral education in the Qur'an}

Education in Indonesia is currently experiencing various problems, as evidenced by the many phenomena that have occurred recently in the context of education, indicating that education in our country is currently experiencing a critical period. In the 1945 Constitution, it has been explained that every citizen has the right to humanely complete education as if he has lost his way. Education began to appear in various forms and meanings along with the times. Now entering the 21st century, education in Indonesia will face multiple challenges and opportunities that will undoubtedly be different from previous times. Therefore, we must always anticipate adapting to the various changes that will continue to occur in the 21 st century.

The term education comes from the word "student", which is given the prefix pe and ballot, which means actions (things, ways, and so on). Education originally comes from the Greek pedagogies, which means guidance given to children. In the Law of the Republic of Indonesia Number 20 of 2003 concerning the National Education System Chapter I Article 1 paragraph 1, it is stated that "Education is a conscious and planned effort to create a learning atmosphere and learning process so that students actively develop their potential. have religious, spiritual strength, self-control, personality, intelligence, noble character, and skills needed for himself, society, nation and state (UU Sisdiknas, 2003).

Moral education has a real urgency in the welfare of life in this world and the hereafter. Moral education also has a vital role in making people aware of depravity towards an Islamic society. Almost all life problems, whether at the individual, family or community level, arise because of the lack of morals possessed by humans today. Honest discussion is not appropriate to be used as a side discussion or complimentary discussion so that it is positioned in the second position, let alone the last serial number. Morals are also not complementary qualities of good human qualities, which will not violate the rules of life if ignored. Morals are the core of the personality of a Muslim and the nature of the ummah, so they must be the basis for human life (Husaini, 2008).

To foster and develop the human person, spiritual and physical aspects must also be carried out in stages. Therefore, maturity, which has an endpoint in optimizing development/growth, can only be achieved if it goes through a process towards the ultimate goal of development or growth. 
However, the desired process in educational efforts is directed, namely directing students to be achieved, forming around and intact personality as individual and social human beings and servants of the creator who devotes himself to Him.

In-Law Number 2 of 1989 concerning the National Education System, article 1 explains that education is a conscious effort to prepare students through guidance, teaching, and training activities for their future roles (UU Sisdiknas, 2003). Even the definition of education is broader in scope as an activity and phenomenon. The meaning of education according to the Law of the Republic of Indonesia Number 20 concerning the National Education System in 2003: Education is a conscious and planned effort to create a learning atmosphere and learning process so that students actively develop their potential to have spiritual, religious, and self-control. Personality, intelligence, noble character, and skills needed by self, society, nation and state.

From the several meanings of education above, what is meant by education is the transformation of knowledge, culture, and values that develop in one generation so that (humans) reach their optimal point of ability. Meanwhile, the goal is to become the next generation to become human beings ready to enter society and become human beings who can benefit the people around them. As the saying goes, "The beauty of life is not seen in how many people we know, but how many happy people know us."

According to A. Mustofa, morality is a person's character or nature, namely a state of the soul that has been trained, so that in the soul, the characteristics are fully attached to which give birth to actions quickly and spontaneously without thinking and wishing (Almutairi, Mustafa, Alessa, Almutairi, \& Almaleh, 2020). Morals reflect nature and the soul, which must be permanent, spontaneous, not temporary, regardless of considerations based on specific interests. Education and morals, which in essence seeks to internalize values, teachings, experiences, attitudes, and systems of life holistically so that they become character, behaviour, and personality.

In cultivating good morals, it can also be obtained from the results of human reasoning (ratio) itself. However, the good character will be stronger if it is based on religious values sourced from the Qur'an. This is understandable because moral values based on religion (Qur'an) have eschatological values, namely noble deeds in the view of religion are not only beneficial in this world but also get rewards in the hereafter. This gift is a stronger motivation in encouraging a person to be noble. Therefore, moral education is the core of all types of education because it leads to the formation of outer behaviour and the human mind to become a balanced human being between physically and mentally (Anisyah \& Siswanto, 2018).

According to Ulwan, moral education is education about ethical policies and the virtues of temperament, habits, behaviours, and attitudes that must be owned and habituated by children to become adults as provisions in navigating their lives (Alfiah, 2020). From the description above, it can be understood that moral education is the process of all efforts made by educators to educate, guide, foster, and shape human beings who are not only intellectual but also have ethics and personality who are accustomed to doing good deeds because they are sincere. Solely because of Allah SWT without coercion and reward, to be humanist.

Morality in the Qur'an is a moral system based on belief in God, then of course, also by the basis of religion itself. And in the teachings of Islamic morality, it is indeed essential, the Prophet Muhammad, as the prophet of the end of time, presence is to 
perfect human morals (Fawziah, 2019). Thus, the basis or primary source of morality is the Qur'an and Hadith, which are the primary sources of religion itself. The personality of the Prophet Muhammad is the most appropriate example to be used as an example in shaping character. Likewise, his friends always rely on the Qur'an and hadith in their daily lives.

\section{METHOD}

This research is qualitative field research that aims to holistically understand the phenomena experienced by the research subjects by describing the data obtained in words or language from the people and observed behaviour (Moleong, 2015). The phenomenon observed in several kinds of literature related to moral education in the Qur'an used at SDIT Darul Huffadz Bekasi by searching some literature to obtain and collect the necessary data. Several sources of supporting literature are also sourced from scientific journals of national and international proceedings. The use of qualitative methods in this research will be beneficial in revealing and describing the situation in detail and depth in the form of natural narratives without data manipulation (Ikhwan, 2021).

\section{RESULT AND DISCUSSION}

\section{Concept of Education of Moral in SDIT Darul Huffadz Bekasi}

SDIT Darul Huffadz Bekasi is located on Jl. Simpang Tiga Buniayu No. 61, Sukarukun, Kec. Sukatani, Bekasi Regency, West Java. As the results of the data obtained by researchers, this elementary school-level Islamic educational institution has implemented Islamic moral education guided by the Qur'an and Sunnah. As for this study, it will focus on the concept of moral education at SDIT Darul Huffadz based on the Qur'an, while al-Hadith will be used as supporting data, as well as other literature related to the discussion.

As stated by the head of SDIT Darul Huffadz, the concept of moral education in the educational institutions he manages is awakened from the awareness of teachers and guardians of students who are most worried about their children's ethical behaviour, thus requiring it to be more guidance than other general education. The results of interviews related to the principal also said that the best guideline in education, especially moral education, is to be guided by the primary approach for Muslims, namely the Qur'an.

"Initially, we were motivated by suggestions from both the teachers themselves and their parents, guardians who entrust their children to our school to emphasize character education for students. This is true as we see today. The crisis that is being faced by society, in general, is behaviour, sad etiquette among teenagers. Wasn't this influenced by his childhood education, which he was less educated about, so he became like most people today? So with this, we are holding it together so that the program runs until now." (Kepsek, 2021).

The above was also confirmed by one of the religious education teachers who should be a teacher, especially a spiritual teacher, to worry about the morals of their students, both when they are still in school and the future. 
"Yes, we are together, and in stages in planning to apply moral education to students. I think the principal's decision with this program is excellent, and I strongly agree." (Teacher, 2021).

The interview results above are clear evidence that the problem with society today is morality. Educational institutions with special moral education programs or even unique programs will be more in demand by the public diaries in other schools.

Morality in the Qur'an is a moral system based on belief in God, then of course, also by the basis of religion itself. So in the teachings of Islamic morality, it is essential, the Prophet Muhammad s.a.w., as the prophet of the end of time, his presence is to perfect human morals. Thus, the basis or primary source of morality is the Qur'an and Hadith, which are the primary sources of religion itself. The personality of the Prophet Muhammad is the most appropriate example to be used as an example in shaping character. Likewise, his friends always rely on the Qur'an and hadith in their daily lives.

The concept of moral education at SDIT Darul Huffadz Bekasi, as said by the deputy principal that in its implementation begins with planning, then formulates the method used. After that, it is applied by homeroom teachers and teachers.

"Regarding moral education here, we discuss together, starting from planning, jointly formulating the right model or method, then distributing the application to students where the most important thing is the teacher and homeroom teacher because they are the ones who meet face to face with students every day." (Wakasek, 2021).

From the deputy principal's statement above, it can be interpreted that in the concept of moral education at SDIT Darul Huffadz Bekasi, there are three stages, the first is planning, namely planning everything needed in moral education, the second organizing is the formulation of methods and models that will be used. And the third is an application, namely the direct implementation of both teachers and homeroom teachers in instilling moral education in students. In more detail, one of the homeroom teachers said;

"Yes, sir, so we held a special meeting together to discuss character education. First of all, we definitely discuss planning, we discuss what plans are needed. Such as competency achievement, assessment, time allocation or the source, namely the Qur'an. Second, we discuss organization, meaning that we organize how later the program can run smoothly according to the previously planned expectations. For example, the method used or the method that is suitable for application. And the third is implementation, we discuss about who will apply this moral education to students, all are obliged to apply it to students, but the most important of all is the teacher and homeroom teacher because we think that they often meet directly with students." (wali kelas, 2021).

Planning is the starting point for the concept of moral education at SDIT Darul Huffadz Bekasi. Planning is an essential activity in moral education because, thorough planning, it is hoped that educational goals can be achieved in the form of changes in behaviour in students, it is also the hope of all parties so that every student becomes a person with character, becomes a graduate who can be considered and becomes a child who makes his parents proud. And valuable for the community. 
Organizing is the next step in moral education at SDIT Darul Hufadz Bekasi. The success of a program, one of the crucial efforts that must be made, is the way of organization. Organizing is a collaboration to achieve the goals that have been set, in this case, those that have been placed in planning. The purpose of organizing is so that the division of tasks in educating or instilling character in students can be organised and responsible. With the division of functions, it is hoped that each member can focus on the assigned tasks through this organisation.

All groups carry out moral education at SDIT Darul Huffadz Bekasi. The principal can socialize to all citizens, educators and students about the importance of moral education to students, where the momentum is very appropriate, namely education as early as possible because the educational institution is a primary educational institution, which will determine the success of the education process, both general and moral education. It is at a later date. A deputy principal can assist and support the duties and work of the principal in implementing moral education at SDIT Darul Huffadz Bekasi. The administrative division, secretary, treasurer, and other ranks can also implement moral education in schools by making themselves an example for their students and being an excellent example. And no less important as the results of the interview above that homeroom teachers and teachers are the most urgent points in the implementation of moral education by the Qur'an.

\section{Education of Moral in SDIT Darul Huffadz Bekasi}

Humans are constantly vying for the most incredible honour, dignity and freedom. Thus, there is no doubt that all human actions or actions in any form are essentially meant to achieve happiness. However, to achieve satisfaction by belief, it can be achieved by obeying Allah's commands as Muslims, namely by avoiding all His prohibitions and carrying out all His commands, as contained in the basic guidelines of every Muslim's life, namely the Qur'an and Hadith (Achmad Yafik Mursyid, 2020).

Morals in Islam are always associated with faith. The two cannot be separated. In the Qur'an, the words faith and charity are mentioned together 50 times (al-Maktabah asShayamilah). Likewise, in the hadith, the form of good deeds is always associated with religion. For example, shame is part of faith, cleanliness is part of faith, doing good to guests, neighbours and saying good is the character of a believer. From these examples, it can be concluded that a person will have faith if it can be seen from his behaviour and actions that behaviour reflects one's faith.

SDIT Darul Huffadz is an introductory level educational institution that includes a moral education program in its academic curriculum to instil good character in students. A good educational institution is an educational institution that prioritizes the value side (cognitive) and the attitude aspect (affective), which is no less important than knowledge. Therefore, SDIT Darul Huffadz Bekasi in the educational process leads to the formation of students' outer and inner behaviour to become human beings balanced between outward and inner, balanced in knowledge and behaviour. Thus, it is necessary to make efforts to motivate and support the formation of strong Muslims who the Qur'an and hadith guide. In this case, the principal of SDIT Darul Huffadz Bekasi, explained how the moral education applied in his school was driven by the Qur'an.

"In instilling morals in students, we jointly examine various references or literature regarding verses of the Qur'an that discuss or touch on moral issues, moral education issues. For example, in Luqman's letter, roughly the point is the 
message or advice of a Luqman to his son. Well, from there, we then look for other references regarding Luqman's letter about how a Luqman educates his children and also how the Prophet Muhammad treated his sons and daughters, as in the letter al-Ahzab." (Kepsek, 2021).

As mentioned by the principal in the interview above, there are at least two guidelines that can be used as role models in moral education. The first is moral education, according to Luqman, because it is one of the letters contained in the Qur'an. Second, namely imitating how the Prophet Muhammad SAW, who is also mentioned in the Qur'an Surah al-Ahzab that the Prophet Muhammad is the best example. As the word of Allah swt below;

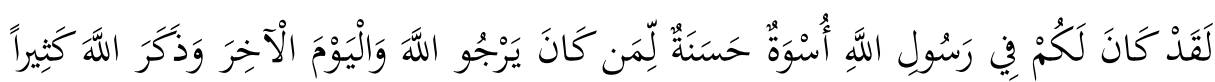

"Indeed, the Messenger of Allah has in you a good role model for you (that is) for those who hope for (the mercy of) Allah and (the coming of) the Day of Judgment and he often mentions Allah." (QS. 33: 21).

It is obvious what Allah swt has said above that the Prophet Muhammad is a good role model for humans who expect the creator's pleasure. Even in the hadith narrated by Imam Ahmad, "When Ayesha's mother radhiyallahu'anhā was asked about the character of the Messenger of Allah, she replied: 'The character of the Messenger of Allah is the Qur'an' (HR Ahmad)". This means that the life of the Prophet is a tangible manifestation of the Qur'an. So it is not an exaggeration to say, as in the hadith above, that his morals are, 'the Qur'an goes'.

Talking about moral education at SDIT Darul Huffadz Bekasi, the vice principal, stated how moral education is in schools.

"In general, the teaching method of Islam is a way of delivering Islamic religious lessons. If the method is associated with the word "special", then it means a special method that has been prepared and considered to be taken in teaching faith, worship, morals and various other Islamic religious subjects." (Wakasek, 2021).

From the description given by the deputy head of SDIT Darul Huffadz Bekasi above, it can be explained that the method of Islamic education is a way of teaching Islamic moral education according to the Qur'an to achieve the desired goals. This opinion was clarified by the religious education teacher regarding the method used.

"Yes, sir, in general moral education here refers to Islamic religious education, while the methods commonly used are the method of habituation, example, punishment, question and answer, and stories. These methods are carried out by teachers who are directly related to students or also homeroom teachers, but basically all groups are also expected to participate for the results as discussed together." (Teacher, 2021).

It can be concluded from the statement above that the moral education applied at SDIT Darul Huffadz Bekasi is through Islamic religious education, meaning that moral education is the essential aspect of Islam. Morals occupy a crucial role in addition to belief in Allah swt so that Islamic religious education becomes the primary way in instilling moral education in students. The methods used are habituation methods, exemplary methods and educational punishment methods. 
Habituation methods carried out at SDIT Darul Huffadz Bekasi include the habit of shaking hands and saying greetings. This activity is routinely carried out every morning when going to class. Usually, the teacher is ready to stand in front of the class to welcome the students. The next habit is to get used to reading prayers before the lesson begins or when the task is over. Reading the prayer together aims to instil a sense of faith and devotion for students. As for the application of the example of SDIT Darul Huffadz Bekasi teachers, among others, religious, discipline, honesty, tolerance, hard work, creativity, independence, curiosity, caring for others and responsibility. There are several examples of educational punishments applied by educators at SDIT Darul Huffadz Bekasi to give sentences to students who violate the rules, for instance, being sour, reprimanding, forbidding to attend lessons, and not greeting. It is hoped that these penalties can make students aware of their mistakes and not do them again in the future.

\section{CONCLUSION}

The Qur'an is the guidance of Allah SWT, which is used as a guide for all His servants, which, when studied, will help us find values that can be used as guidelines in solving various life problems. The existence of a Muslim reflects his moral behaviour in everyday life. If the Qur'an has been embedded in the soul of every human being and applied in everyday life, then good morals will be realized to provide peace and inner peace. Moral education is education that prioritizes the value side (cognitive) and the attitude aspect (affective). Therefore, moral education leads to the formation of human outer and inner behaviour to become a balanced human being physically and mentally. Thus, it is necessary to make efforts to motivate and support the formation of strong Muslims who the Qur'an and hadith guide. Likewise, the Bekasi Integrated Islamic Elementary School (SDIT) instils character in its students through Islamic religious education through several educational methods. The writer hopes that more and more educational institutions in Indonesia will have moral education programs in their institutions. In this way, sentences such as juvenile moral crisis, the crisis of etiquette and so on are cut off and changed to teenagers who are honest or civilized human beings.

\section{REFERENCES}

[1] Achmad Yafik Mursyid. (2020). Resepsi Estetis Terhadap Al-Qur'an (Implikasi Teori Resepsi Estetis Navid Kermani Terhadap Dimensi Musikalik Al-Qur'an) . 2013.

[2] Al-Attas. (1996). Konsep Pendidikan Dalam Islam. Terj. dari Bahasa Inggris oleh Haidar Bagis. Bandung: Mizan.

[3] Alfiah, S. (2020). Konsep Pendidikan Islam Anak Usia Dini Perspektif AlGhazali Dan Abdullah Nashih Ulwan (Studi Komparasi Pemikiran). WISDOM: Jurnal Pendidikan Anak Usia Dini. https://doi.org/10.21154/wisdom.v1i1.2136

[4] Almutairi, A. F., Mustafa, A. B., Alessa, Y. M., Almutairi, S. B., \& Almaleh, Y. (2020). Public trust and compliance with the precautionary measures against COVID-19 employed by authorities in Saudi Arabia. Risk Management and Healthcare Policy, $13(1)$

753-760. 
https://doi.org/https://doi.org/10.2147/RMHP.S257287

[5] Althof, W., \& Berkowitz, M. (2006). Moral Education and Character Education: Their Relationship and Roles in Citizenship Education. Journal of Moral Education - J MORAL EDUC, 35(1), 495-518.

[6] Anisyah, Y., \& Siswanto. (2018). Revitalisasi Nilai - Nilai Qur' ani Dalam Pendidikan Islam Era Revolusi Industri 4.0. Islamuna Jurnal Studi Islam.

[7] Anwar, S. (2021a). Internalisasi Nilai Pendidikan Akhlak dalam Surat AlHujurat Tafsir fi ZIlalil Qur'an. JIE: Journal of Islamic Edication, 6(1), 1-12.

[8] Anwar, S. (2021b). Pendidikan Karakter: Kajian Perspektif Tafsir fi Zilalil Qur'an. Tulungagung: STAI Muhammadiyah Tulungagung.

[9] Bafadhol, I. (2017). Pendidikan Akhlak Dalam Perspektif Islam. Edukasi Islami: Jurnal Pendidikan Islam, 6(2), 19.

[10] Darmadi, H. (2015). Tugas, peran, kompetensi, dan tanggung jawab menjadi guru profesional.

[11] Daroini, I., Ikhwan, A., \& Saputro, A. D. (2020). Internalization of Social Care Values With Infaq: Case Study at MTsN 6 Ponorogo, East Java, Indonesia. AlTadzkiyyah: Jurnal Pendidikan Islam, 11(2), 175-189.

[12] Fawziah, F. E. (2019). Konsepsi dan Implementasi Pendidikan Karakter dalam Islam. Andragogi: Jurnal Diklat Teknis Pendidikan Dan Keagamaan. https://doi.org/10.36052/andragogi.v7i1.67

[13] Guru. (2021). Wawancara Terstruktur Guru PAI.

[14] Husaini, U. (2008). Manajemen Teori Praktek Dan Riset Pendidikan. Jakarta: Bumi Aksara.

[15] Ikhwan, A. (2019). Public Relations in an Islamic Perspective; Implementation Study at Madrasah. At-Turats: Jurnal Pemikiran Pendidikan Islam, 13(2), 105117. https://doi.org/https://doi.org/10.24260/at-turats.v13i2.996

[16] Ikhwan, A. (2021). Metode Penelitian Dasar (Mengenal Model Penelitian dan Sistematikanya). Tulungagung: STAI Muhammadiyah Tulungagung.

[17] Kepsek. (2021). Wawancara Terstruktur Kepala Sekolah.

[18] Mahmud. (2017). Psikologi Pendidikan. Bandung: Pustaka Setia.

[19] Mardiana, D., Razaq, A. R., \& Umiarso, U. (2020). Development of Islamic Education: The Multidisciplinary, Interdisciplinary and Transdisciplinary Approaches. Al-Hayat: Journal of Islamic Education, 4(1), 58-68. https://doi.org/10.35723/ajie.v4i1.97

[20] Marques, J. M. R., La Falce, J. L., Marques, F. M. F. R., De Muylder, C. F., \& Silva, J. T. M. (2019). The relationship between organizational commitment, knowledge transfer and knowledge management maturity. Journal of Knowledge Management. https://doi.org/10.1108/JKM-03-2018-0199

[21] Maryam, Y., Putri, T. J., \& Firmansyah, D. (2018). Analisis Nilai Moralitas Pada Tokoh Utama Dilan Dalam Novel Dilan (Dia Adalah Dilanku Tahun 1990) Karya Pidi Baiq. Parole (Jurnal Pendidikan Bahasa Dan Sastra Indonesia), 1(6), 929-936. https://doi.org/10.22460/P.V1I6P929-936.1652 
[22] Moleong, L. J. (2015). Metode Penelitian Kualitatif. Bandung: Remaja Rosdakarya.

[23] Nabila. (2021). Tujuan Pendidikan Islam. Jurnal Pendidikan Indonesia, 2(5). https://doi.org/10.36418/japendi.v2i5.170

[24] Nisa, A. (2018). Analisis Kenakalan Siswa dan implikasinya Terhadap Layanan Bimbingan Konseling. Jurnal EDUKASI (Media Kajian Bimbingan Konseling), 4(2), 102-124.

[25] Nurhartanto, A. (2015). Nilai-Nilai Pendidikan akhlak dalam Al-Qur'an Surat Ali Imran ayat 159-160. Jurnal Studi Islam Profetika, 16(2), 155. https://doi.org/https://doi.org/10.23917/profetika.v16i2.1851

[26] Sadjad, A. (2020). Pendidikan Akhlak Perspektif al-Imam Al-Ghazali. Transformasi : Jurnal Studi Agama Islam, 13(1), 110-126.

[27] Sardiyanah. (2020). KONSEP EVALUASI DALAM PENDIDIKAN. Jurnal AlQalam: Jurnal Kajian Islam \& Pendidikan. https://doi.org/10.47435/alqalam.v8i1.199

[28] Syamsu. (2015). Strategi Pembelajaran Pendidikan Agama Islam Antisipasi Krisis Akhlak Peserta Didik Pada Sma Negeri Di Palopo. INFERENSI: Jurnal Penelitian Sosial Keagamaan, 9(2), 377.

[29] UU Sisdiknas, N. 20. (2003). Undang-Undang Sistem Pendidikan Nasional. Records Management Journal, 1(2).

[30] Wakasek. (2021). Wawancara Terstruktur Wakil Kepala Sekolah.

[31] wali kelas. (2021). Wawancara Terstruktur Wali Kelas VI.

[32]Zulida. (2017). Konsep Pendidikan Akhlak Dalam Islam. Dewantara, III. 